УДК 347.1 (4)

DOI https://doi.org/10.32849/2663-5313/2020.8.03

Ірина Гелещька,

канд. юрид. наук,

заступник директора з наукової та навчально-виробничої роботи

Галищького коледжу імені В'ячеслава Чорновола

Віталій Скиба,

адвокат,

викладач кафедри права

Галицького коледжу імені В’ячеслава Чорновола

\title{
ПРЕДСТАВНИЦТВО У ЦИВІЛЬНО-ПРАВОВИХ ВІДНОСИНАХ ТРАНСПЛАНТАЦІЇ АНАТОМІЧНИХ МАТЕРІАЛІВ ВІД ПОМЕРЛИХ ОСІБ
}

У статті на основі норм чинного законодавства та аналізу поглядів науковців окреслено проблемні питання, що пов'язані з особливостями застосуванням інституту представниитва у разі трансплантації анатомічних матеріалів після смерті особи. Зауважується, що у відносинах посмертного донорства мають місие $і$ договірне представниитво, і представництво за законом. Наголошується на тому, що договірне представництво, яке виникає на підставі договору доручення, здійснюється надалі не на підставі довіреності, а на підставі письмової заяви, яка не є характерним документом у представницьких правовідносинах. Проведено порівняльний аналіз заяви із договором доручення і довіреністю та визначено ї̈ правову природу. У результаті дослідження запропоновано вирішення вказаної проблеми шляхом внесення змін до иивільного законодавства.

Авторами з'ясовано категорію «повноваження представника за заявою» у контексті права чи обов'язку надавати згоду на трансплантаиію анатомічних матеріалів померлої особи. На підставі аналізу правових норм зроблено висновок, що це є правом повноважного представника, та запропоновано у змісті заяви зазначити саме «повноважний представник має право надати згоду».

Детально розкрито порядок здійснення повноважним представником відмови від надання згоди на трансплантацію як за життя, так і після смерті особи. Виокремлено правові наслідки такої відмови залежно від періоду, в якому вона була здійснена. Якщо представник відмовиться надати письмову згоду після смерті особи, запропоновано за аналогією застосувати правило, яке міститься у нормах щодо відмови від прийняття спадщини за заповітом (ст. 1273-1275 ЦК України), і закріпити таке право за подружжям, родичами або особою, яка буде здійснювати поховання померлого. Констатується, що повноважний представник має право відмовитися від надання згоди на трансплантацію анатомічних матеріалів ще за життя особи, і жодні правові наслідки такої відмови не можуть мати місие, хоча б із тієї позищії, що такою відмовою не завдаються збитки особі, які призначила повноважного представника.

Надано авторські висновки і позииї щодо вдосконалення законодавства у зазначеній сфері.

Ключові слова: трансплантація, представництво за законом, договірне представництво, письмова заява, повноважний представник, відмова від повноважень.

Постановка проблеми. Сьогодні Україна перебуває на етапі реформування різних аспектів своєї діяльності, беззаперечно, вагомих трансформацій зазнає і медична сфера. Важливим складником реформування медицини стали зміни у сфері трансплантації анатомічних матеріалів людини, актуальність яких неможливо заперечувати, оскільки сотні тисяч хворих українців роками чекають своєї черги у праві на життя, хоча і не кожен досягає фінішу у цій боротьбі.

Право на життя як форму руху матерії мають усі живі істоти. Але щодо людини це право має набагато глибший зміст. Виключно людина наділена розумом та свідомістю, а тому є вищою, притому соціальною, істотою, оскільки її життя невіддільне від розвитку суспільства. Без життя (без права на нього) втрачають сенс інші природні та соціальні цінності: навколишне середовище, матеріальний достаток, мирне співіснування, розвиток демократичних засад тощо.

Початок 2019 року ознаменувався набранням чинності Законом України «Про застосування трансплантації анатомічних 
матеріалів людини [1] (далі - Закон), який врегульовує питання трансплантації людських органів та інших анатомічних матеріалів для збереження життя інших людей.

Трансплантація - один із найскладніших та водночас найбільш ефективний метод лікування складних захворювань у випадках, коли інші методи уже є безрезультатними. Досягнення сучасної медицини сприяють розвитку лікування у такий спосіб та допомагають покращити якість життя тисячі хворих.

Проте сьогодні проблема полягає у тому, що сфера регулювання трансплантології $€$ новою, нечітко визначеною, та водночас ускладнюється відсутністю єдиних міжнародних стандартів стосовно донорства та трансплантології. Більшість норм міжнародного характеру мають так званий загальний, рекомендаційний характер, а отже, зазначена сфера визначається внутрішньодержавним вибором кожної країни.

Неможливо не вказати на такі перешкоди впровадження новел на практиці, як відсутність чіткого механізму їх реалізації, упереджене ставлення суспільства та недостатність фінансування з боку держави.

Однією з ключових причин такого стану речей є вади правового регулювання. Насамперед проблемним питанням залишається посмертне донорство. У дискусійному полі перебуває визначення права особи на розпорядження своїм тілом після іï смерті в системі цивільних прав особи, а також питання правомочностей членів сім'ї померлого чи інших осіб щодо розпорядження його тілом після смерті.

Аналіз останніх досліджень та публікацій. Проблеми правового регулювання відносин донорства та трансплантації розглядалися у наукових працях таких вчених, як: Г. Анікіна, М. Брюховецька, С. Гринчак, К. Ільщенкова, М. Малеїн, М. Малеїна, Н. Маргацька, I. Міщук, I. Пташник, I. Сенюта, С. Стеценко та інші. Водночас особливості інституту представництва у відносинах посмертного донорства малодосліджені і потребують додаткового вивчення.

Метою статті є дослідження особливостей застосування інституту представництва у цивільно-правових відносинах трансплантації анатомічних матеріалів від померлих осіб.

Виклад основного матеріалу. Відповідно до ст. 1 Закону під трансплантацією розуміється спеціальний метод лікування, що полягає у пересадці анатомічного матеріалу людини від донора реципієнту і спрямований на відновлення здоров'я людини.
Натепер у більшості країн саме органи померлих переважно використовуються для трансплантації. Здавалося б, у випадку вилучення органів у померлої людини не має виникати жодних перешкод. Але вони є, і досить складні. Адже проблема трансплантації органів і тканин - це проблема особистих прав людини, тому, окрім численних медичних аспектів, вагоме значення має і ряд фундаментальних правових, моральних і етичних питань, пов'язаних із трансплантологією.

Найбільш складним і дискусійним залишається питання щодо згоди донора на вилучення органів після його смерті, що зумовлює важливість розробки зваженої позиції стосовно критеріїв правомірності застосування посмертного донорства.

Конституція України проголошує право кожної людини на особисту недоторканість, і здійснення медичного втручання без згоди людини є таким, що порушує їі права. Подальший свій розвиток та більш детальну регламентацію зазначене право знаходить у положеннях гл. 21 Цивільного кодексу України [2] (далі - ЦК України). Особиста недоторканість фізичної особи виступає в площині індивідуальної можливості розпоряджатися цим правом, свобідної волі в питанні, бути їй донором чи ні. Відповідно до статті 17 Додаткового протоколу до Конвенції про права людини та біомедицину щодо трансплантації органів і тканин людини органи і тканини не видаляються у померлої особи, якщо не має отриманої у встановленому порядку на те згоди [3].

За правилами ст. 16 Закону кожна повнолітня дієздатна особа має право надати згоду чи незгоду на вилучення анатомічних матеріалів з її тіла для трансплантації після її смерті. Окрім того, Закон дозволяє отримання згоди на вилучення анатомічних матеріалів від донора-трупа і від інших осіб, допускаючи таким чином існування своєрідних представницьких правовідносин, суть яких зводиться до того, що кожна повнолітня дієздатна особа має право призначити свого повноважного представника, який після смерті цієї особи надасть згоду на вилучення органів 3 її тіла (ч. 7 ст. 16 Закону). Таким представником може бути лише повнолітня дієздатна особа, яка добровільно та свідомо погодилася на це.

Як бачимо, у даному випадку має місце різновид так званого представництва за довіреністю (ст. 244 ЦК України), або, як ще його називають, договірного чи добровільного представництва. Хоча оформляється воно не класичним договором доручення і виданою на його підставі довіреністю, а письмовою заявою про призначення повноважного 
представника, засвідченою особистими підписами осіб, які беруть участь у вказаних правовідносинах.

За загальним правилом і договір доручення, і довіреність - це правочини. Договір доручення - двосторонній і являє собою погоджену дію двох сторін (ч. 4 ст. 202 ЦК України), довіреність - односторонній, бо за правилами ч. 3 ст. 202 ЦК України для її вчинення досить волевиявлення однієї сторони. У контексті якого з цих двох правочинів розглядати заяву про призначення повноважного представника за правилами ч. 8 ст. 16 Закону?

За змістом Додатку 4 до Порядку надання письмової згоди живого донора на вилучення у нього анатомічних матеріалів та письмової відмови від раніше наданої такої згоди, письмової згоди або незгоди чи відкликання наданої раніше згоди на вилучення анатомічних матеріалів 3 тіла особи для трансплантації та/або виготовлення біоімплантатів після визначення іï стану як незворотня смерть, а також подання письмової зави про призначення, зміну чи відкликання повноважного представника, затвердженого постановою Кабінету Міністрів України від 27 грудня 2018 р. № 1211 [4], така заява фактично врегульовує питання визначення представника, який має прийняти рішення після смерті фізичної особи щодо надання згоди на вилучення анатомічних матеріалів з їі тіла. Загалом, така заява досить близька за формою та змістом до довіреності. Обидва документи можуть трактуватися як письмові документи, що видаються однією особою іншій особі для представництва перед третіми особами (ч. 3 ст. 244 ЦК України). Обидва документи визначають обсяг повноважень представника. Але у довіреності, на відміну від такої заяви, не міститься підпис представника, яким засвідчується надання згоди на вчинення дій, визначених у довіреності, а у заяві, на відміну від довіреності, не може встановлюватися конкретний строк іiї дії. Зазвичай такі заяви будуть правомочними або до моменту їх відкликання (відмови) чи зміни повноважного представника, або до того моменту, коли уповноважений представник надасть (не надасть) згоду на вилучення анатомічних матеріалів після смерті. Оскільки у такій заяві містяться волевиявлення обох сторін, остання не може розглядатися в контексті одностороннього правочину.

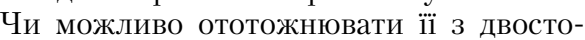
роннім правочином - договором, у даному випадку договором доручення? Також не впевнені. Як зазначалося вище, договір доручення - це двостороння домовленість двох сторін, більше того, вказаний договір належить до групи так званих фідуціарних договорів, тобто таких, які засновані на високому ступені довіри обох сторін одна до одної. Довіритель має бути впевненим у повіреному більше, ніж у самому собі. I не виключено, що елементи такої фідуціарності присутні у даному випадку. Надати право визначати долю власних анатомічних матеріалів після смерті можливо лише особі, з якою перебуваєш у близьких, довірчих відносинах. Заява містить підписи обох сторін як вираз волевиявлення обох сторін. Ставлячи підписи на заяві, сторони виражають свою згоду на виникнення між ними цивільно-правових відносин у майбутньому, що певною мірою ідентично з класичним цивільно-правовим договором. Більше того, дану заяву можна розглядати як підставу виникнення так званих внутрішніх відносин договірного представництва, що є передумовою для здійснення отриманих повноважень у відносинах з третіми особами (зовнішні відносини договірного представництва). Але, з іншого боку, така заява подається до певного уповноваженого органу, що нехарактерно для договору. Максимум, що може мати місце у договорах, - це їх посвідчення уповноваженими особами. Тому таку заяву навряд чи можливо ототожнити із двостороннім правочином (договором) у розумінні ЦК України, хоча окремі елементи цивільно-правового договору у ній мають місце.

Сдине, що можливо допускати, - це всетаки наявність усної домовленості, яка за своїм змістом тотожна договору доручення. Така домовленість (договір) між уповноваженим представником i повнолітньою дієздатною особою передує оформленню та підписанню заяви; без неї виникнення представницьких правовідносин неможливе. Таким чином, не виключено, що частину 1 ст. 244 ЦК України варто було б доповнити положенням, за яким представництво, яке грунтується на договорі, може здійснюватися не лише за довіреністю, але й і за заявою.

На можливості застосування для вирішення питань щодо лікування та догляду у відносинах між пацієнтом та призначеної ним довіреної особи за аналогією положень договору доручення наголошувала свого часу і Г. Миронова [5, с. 123]. Дослідження, наведені у іï праці, присвячені представництву пацієнта за довіреністю у контексті правової конкретизації суб'єктів та процедур прийняття медичних рішень у клінічних випадках, обтяжених нездатністю пацієнта до волевиявлення. Автор вважає, що такі питання можна вирішити шляхом завчасно виданої довіреності із визначеним обсягом повноважень довіреної особи-представ- 
ника щодо медичного втручання [5, с. 119]. У вказаній праці не розглядалася можливість видачі довіреності особі-представнику на надання згоди щодо вилучення анатомічних матеріалів після смерті особи, але це абсолютно не виключає можливості розглядати це питання в контексті посмертного донорства. На нашу думку, це було би більш доцільним, аніж оформлення письмової заяви про призначення уповноваженого представника.

Не виключає законодавець також існування у відносинах посмертного донорства й іншого різновиду представництва - представництва за законом. Так, крім повноважного представника, надавати згоду на вилучення анатомічних матеріалів мають право і близькі родичі померлого. Очевидно, що випадків, коли буде мати місце трансплантація за згодою родичів померлого, буде більше. Не думаємо, що українці масово почнуть вирішувати посмертну долю власних анатомічних матеріалів за життя шляхом написання заяви-згоди чи призначенням уповноваженого представника. Для багатьох 3 нас написати таку заяву - то як скласти заповіт на випадок своє смерті: і одне, й інше означатиме уже один крок у засвіти. Не варто сподіватися на таку свідомість українців; для такого прогресу потрібен час. Та й мало хто обізнаний у наявності таких правових норм. Стикаються 3 ними ті, перед ким проблема трансплантації постала досить серйозно.

Ще один момент, на якому варто було б зупинитися, - це з'ясування повноважень уповноваженого представника за заявою У дефініції ч. 7 ст. 16 Закону та у змісті самої заяви про призначення представника задекларовано, що уповноважений представник «надасть згоду» на вилучення після смерті особи $з$ її тіла анатомічних матеріалів для трансплантації та/або виготовлення біоімплантатів. Представник зобов'язаний чи має право надати таку згоду? Аналіз положень Закону, зокрема ч. 3 ст. 17, дає нам право зробити висновок, що надання згоди на посмертне донорство все-таки є правом, а не обов'язком уповноваженого представника, оскільки відсутність письмової згоди повноважного представника за умовами наведеної вище норми забороняє вилучення анатомічних матеріалів у померлої особи. Очевидно, зміст заяви має бути сформульований більш коректно, i, замість «повноважений представник надасть згоду», краще зазначити «повноважний представник має право надати згоду».

Беззаперечно, що взяти на себе сміливість вирішувати питання щодо тілесної цілісності померлої особи наважиться не кожен. Певно, саме тому ч. 10 ст. 16 Закону особі, яку призначено повноважним представником, надає право у будь-який час відмовитися бути повноважним представником, вчинивши необхідні дії. Суб'єкт, якому подано цю заяву, повинен протягом трьох робочих днів письмово поінформувати про таку відмову особу, яка призначила цього повноважного представника. На думку М. М. Ковальського, «надання особі можливості відмовитись від представництва ускладнює всю процедуру вилучення та передачі органів, оскільки в результаті відмови первісного представника та невчасного повідомлення потенційний донор може не встигнути призначити іншого представника, та його воля залишиться нереалізованою. Крім того, виникає питання, чи виникатимуть правові наслідки для представника, якщо особа помре протягом цих трьох днів та не встигне отримати повідомлення щодо його відмови» [6, с. 82]. Звичайно, таких ситуацій не варто виключати. Але ставити питання про застосування правових наслідків такої відмови навряд чи $є$ доцільним. Нами уже зазначалося вище, що такі відносини мають фідуціарний характер, тобто їм притаманний високий ступінь довіри сторін одна до одної. Загальновідомо, що однією з ознак фідуціарного правочину є право сторін відмовитися від нього. I положеннями про договір доручення, і правовими нормами про довіреність (як приклади фідуціарних правочинів у цивільному праві) можливість відмови сторін врегульована (ст. 250 ЦК України, ч. 2 ст. 1008 ЦК України). Якщо ми розглядаємо означені відносини в контексті цивільно-правового представництва, то логічно, що повноважний представник має право на відмову від вчинення дій, визначених у заяві, і про будь-які правові наслідки такої відмови не видається можливим говорити хоча б із тієї позиції, що такою відмовою не завдаються жодні збитки особі, які призначила повноважного представника. Якщо особа не встигне призначити іншого повноважного представника, то питання трансплантації анатомічних матеріалів після її смерті буде вирішуватися одним із подружжя або іншими родичами.

Необхідно більш детально врегулювати у законодавстві і випадки, коли уповноважений представник відмовиться надавати згоду на трансплантацію після смерті особи. Звичайно, у такому випадку найбільш доцільним буде з'ясування думки родичів померлого. I хоча законодавець детально цього випадку не врегулював, вважаємо, що за аналогією можливо застосувати правило, яке міститься у нормах щодо відмови від прийняття спад- 
щини за заповітом (ст. 1273-1275 ЦК України), і у випадках, коли повноважний представник відмовиться від надання згоди на посмертне донорство після смерті особи, закріпити таке право за родичами або особою, яка буде здійснювати поховання померлого. Окремі науковці пропонують створити своєрідний ієрархічний перелік родичів та членів сім'ї, думка яких почергово буде з'ясовуватися у разі розбіжностей щодо надання (ненадання) згоди на трансплантацію [7, с. 123]. Не думаємо, що варто підтримувати цю позиції, оскільки це питання вже врегульоване ч. 11 ст. 16 Закону, де чітко зазначена послідовність у зверненні трансплант-координатора за отриманням згоди на вилучення органів. Це відповідно інший з подружжя, а далі у наведеному порядку близькі родичі цієї особи (діти, батьки, рідні брати та сестри). Зрештою, оскільки питання посмертного донорства дещо близькі до питань спадкування, не виключено, що таку ситуацію можливо вирішувати за принципом закликання до спадкування спадкоємців за законом. Якщо наявні спадкоємці першої черги (один із подружжя, діти, батьки померлого), то думка спадкоємців другої черги (рідні брати і сестри померлого) не береться до уваги. I оскільки законодавець серед осіб, які мають право надавати згоду на посмертне донорство, насамперед зазначає іншого з подружжя, а вже потім інших родичів померлого, то цілком очевидно, що думка подружжя і буде вирішувати питання щодо трансплантації анатомічних матеріалів у померлої особи. І лише у разі його відсутності таке питання буде ставитися перед дітьми, батьками, рідними братами, сестрами чи особою, яка зобов'язалася поховати померлого.

\section{Висновки}

Підсумовуючи наведене, вище варто зазначити, що інститут представництва у цивільно-правових відносинах трансплантації анатомічних матеріалів від померлих осіб виступає однією із гарантій реального та повного здійснення суб'єктивних прав фізичними особами, але водночас потребує більш детального розгляду та врегулювання. Законодавчі норми, якими задекларовано можливість застосування представництва при посмертному донорстві, визначають основні засади і алгоритм призначення повноважного представника та обсяг його повноважень.

3 огляду на особливості правової природи відносин у сфері трансплантації, цілком очевидним є те, що пріоритетним виступає їх цивільно-правове регулювання, а тому необхідно узгодити норми, які регулюють відносини представництва при посмертному донорстві, 3 положеннями, які регулюють інститут представництва у цивільному праві.

Перспективними вважаємо проведення подальших розвідок у даному науковому напрямі, оскільки чинне законодавство лише певною мірою вирішує окреслену проблему, а практичне його застосування може викликати певні неузгодженості.

\section{Список використаних джерел:}

1. Про застосування трансплантації анатомічних матеріалів людині : Закон України від 17 травня 2018 року № 2427-VIII. URL : https:// zakon.rada.gov.ua/laws/show/2427-19 (дата звернення: 22.07.2020).

2. Цивільний Кодекс України : Закон України від 16 січня 2003 року № 435-IV. URL https://zakon.rada.gov.ua/laws/show/435-15 (дата звернення: 22.07.2020)

3. Додатковий протокол до Конвенції про права людини та біомедицину щодо трансплантації органів і тканин людини (ETS N 186) від 24 січня 2002 року № 994_684. URL : https:// zakon.rada.gov.ua/laws/show/994_684 (дата звернення: 22.07.2020).

4. Порядок надання письмової згоди живого донора на вилучення у нього анатомічних матеріалів та письмової відмови від раніше наданої такої згоди, письмової згоди або незгоди чи відкликання наданої раніше згоди на вилучення анатомічних матеріалів з тіла особи для трансплантації та/або виготовлення біоімплантатів після визначення її стану як незворотня смерть, а також подання письмової заяви про призначення, зміну чи відкликання повноважного представника Затверджений постановою Кабінету Міністрів України від 27 грудня 2018 року № 1211. URL : https://zakon.rada.gov.ua/laws/show/1211-2018 (дата звернення: 22.07.2020).

5. Миронова Г. Представництво пацієнта за довіреністю: цивільно-правова характеристика правочинів. Вісник Академії правових наук України. 2011. № 3. С. 117-128.

6. Ковальський М.M. Представництво в цивільно-правових відносинах, що виникають під час надання медичних послуг трансплантації анатомічних матеріалів від померлих осіб. Науковий вісник публічного та приватного права. 2019. Випуск 3. Том. 2. С. 80-84. URL : http://nvppp.in.ua/vip/2019/3/tom_2/14.pdf (дата звернення: 22.07.2020)

7. Брюховецька М.С. Цивільно-правове регулювання посмертного донорства : дис. канд. юр. наук : 12.00 .03 . Київ, 2017. 230 с. 
Iryna Geletska, Vitalii Skyba. Representation in civil law relations on transplantation of anatomic materials from deceased persons

Based on the norms of the current legislation and the analysis of the scientists' researches, the article outlines the comprehensive issues related to the peculiarities of the use of the institution of representation in the transplantation of anatomical materials after the death of a person. It is emphasized that in the relationship of posthumous donation there is the representation by proxy as well as the representation under the law. The representation by proxy, which is based on the contract, is carried out in the future not on the basis of a proxy, but on the grounds of written statement, which is a not a common document in representative legal relations. A comparative analysis of a written statement with an agency agreement and a proxy has been performed and its legal nature has been identified as well. According to the results of this study, the solution of the following problem is suggested by means of the amendments to the civil law.

The authors of the article identify the category of the powers of the representative with a statement in the context of the right or obligation to give a consent to the transplantation of anatomical materials of the deceased. Based on the analysis of legal norms, it is summerised that this is the right of the authorized representative and it is suggested to indicate in the content of the statement "the authorized representative has the right to give a consent."

The procedure for the refusal of an authorized representative to give a consent to a transplantation during life and after the death of a person is described in detail. The legal consequences of such a refusal and the consequences of the refusal in different periods in which it was carried out are highlighted. If the representative refuses to give a written consent after the death of the person, it is proposed to apply by analogy the rule contained in the legal norns for Refusal from Acceptance of Inheritance (Articles 1273-1275 of the Civil Code of Ukraine) and to assign such a right to spouses, relatives or person that will bury the deceased. The analysis of the data clearly indicates that the authorized representative has the right to refuse in giving a consent to the transplantation of anatomical materials during the life of the person, and no legal consequences of such refusal can take place, at least from the position that such refusal does not harm the person who appointed the authorized representative.

Author's conclusions and views on improvement of the legislation in the mentioned field of research are given.

Key words: transplantation, representation under the law, representation by proxy, written statement, authorized representative, refusal from powers. 